\title{
MCMC 法による位相速度の逆解析における地盤モデルの推定精度の評価 ESTIMATION OF MODEL UNCERTAINTY OF S-WAVE VELOCITY PROFILE FROM INVERSION OF SURFACE-WAVE PHASE VELOCITY USING MCMC METHOD
}

\author{
山中浩明*
}

\section{Hiroaki YAMANAKA}

\begin{abstract}
Applicability of Markov Chain Monte Carlo (MCMC) method in Rayleigh wave phase velocity inversion in shallow soil is examined. Numerical examination was conducted using synthetic phase velocity. Frequency distributions of S-wave velocities and thicknesses of the sampled models were used to estimate optimal model and its uncertainty. The shallow S-wave velocity model was well reconstructed from the inversion. The uncertainties of the parameters are linearly related with the observational errors. The sampled models were used to estimate uncertainty of $1 \mathrm{D}$ amplification factors. We furthermore applied the inversion method to actual data from microtremor explorations in damaged area during the 2007 Noto-Hanto earthquake. It is concluded that the MCMC inversion method is effective to estimate optimal model together with their uncertainty.
\end{abstract}

Keywords : Markov Chain Monte Carlo method, Phase velocity, Inversion, S-wave profile, Site amplification マルコフ連鎖モンテカルロ法，位相速度，逆解析，S波速度構造，増幅特性

\section{1. はじめに}

地盤の $\mathrm{S}$ 波速度分布に関する情報は，地震動特性を評価する際に 欠くことができないものである。表層地盤の $\mathrm{S}$ 波速度構造の調査に は，様々な方法が使われているが，簡易な方法として微動を用いる 方法がある。とくに, 微動探查法は, 微動を複数の地点で同時に計 測し，その表面波位相速度から $\mathrm{S}$ 波速度分布を推定する方法であり， 基本的な理論的背景は明解である 1 )。すでに，この方法は，多くの 調査研究での適用実績があり, 様々な深度スケールの地盤探查に用 いられている 11,2 )。

微動探查では，レイリー波の位相速度から地盤モデルを推定する ことが一般的であり，位相速度の観測值と理論值の差が最小になる ように成層地盤の $\mathrm{S}$ 波速度と厚さを決定することになる。地震学や 地震工学の分野では，表面波位相速度の逆解析に対して様々な手法 が提案されている。1990 年頃までは, 擬似線形化による最小 2 乗法 に基づく逆解析がほとんどであった ${ }^{1)} 。 1990$ 年代後半になり，遺伝 的アルゴリズムなどのヒューリステック探索法の適用が試みられて いる 4)。これらの方法には, アルゴリズムの高ロバスト性や初期モ デルへの低い依存性などの利点があり, 最近の地盤調查の実務や研 究でもこれらの逆解析アプローチがよく使われている5)。

位相速度の逆解析結果では, 観測值を最もよく説明できる成層地 盤モデルがひとつだけ示されることが多く, 得られたモデルの各パ
ラメータがどの程度の精度で推定されているかについての検討は少 ない。一般的に, 逆解析では, 観測值である位相速度の計測上の誤 差が理論モデルを介して，誤差伝播則によってモデルのパラメータ のばらつきに変換される。従って，モデルパラメータの推定精度を 理解するには，位相速度の観測值のばらつきがどのようにパラメー 夕に影響するかを検討する必要がある。しかし，位相速度の逆解析 における誤差評価式が非線形であることもあり，解の近傍での線形 近似による誤差伝播則が幅広い範囲で十分であるかについて議論の 余地がある。最近, 数值統計学的な手法を用いて, 深部地盤を伝播 するレイリー波の位相速度の逆解析における観測值の誤差の影響を 評価する試みが行われている6)。

本研究では，マルコフ連鎖モンテカルロ法を用いて，短周期のレ イリー波の位相速度の観測值のばらつきが表層地盤モデルの推定結 果，その精度，さらには地盤増幅特性などに及ぼす影響について検 討を行った。

\section{MCMC 法による位相速度の逆解析方法}

微動探査によるレイリー波の位相速度の逆解析では, 理論モデル のパラメータ $\mathbf{m}$ の計算值 $C\left(T_{i}\right)$ と観測值 $O\left(T_{i}\right)$ の誤差の 2 乗和 $E(\mathbf{m})$

$$
E(\mathbf{m})=\sum_{i}\left[\frac{O\left(T_{i}\right)-C\left(T_{i}\right)}{\sigma\left(T_{i}\right)}\right]^{2}
$$

\footnotetext{
* 東京工業大学大学院総合理工学研究科 教授 $\cdot$ 工博
}

Prof., Interdisciplinary Graduate School of Science and Engineering, Tokyo Institute of Technology, Dr. Eng. 
がモデル推定の基準 (misfit) となることが多い ${ }^{6}$ 。ここで, $\sigma\left(T_{i}\right)$ は, 周期 $T i$ における観測位相速度の標準偏差である。

この misfit は, 以下のようにモデルの確率分布と関係づけられる 7)。ベイズ定理によれば，一般に，データ $\mathrm{d}$ が得られた際のモデル $\mathrm{m}$ となる確率密度関数は,

$$
p(\mathbf{m} \mid \mathbf{d})=p(\mathbf{d} \mid \mathbf{m}) p(\mathbf{m}) / p(\mathbf{d})
$$

と書ける。 $p(\mathrm{~A} \mid \mathrm{B})$ は, $\mathrm{B}$ が起こったときに, $\mathrm{A}$ が発生する条件付確 率密度関数である。 $p(\mathrm{~d})$ は, 観測デー夕の確率密度関数であり, モ デルとは独立なので, 定数と考えてよい。また, 事前にパラメータ の情報がなく, $p(\mathbf{m})$ が一様な確率分布となるとすれば, (2)式は,

$$
p(\mathbf{m} \mid \mathbf{d}) \propto p(\mathbf{d} \mid \mathbf{m})
$$

となる。ここで, $p(\mathbf{d} \mid \mathbf{m})$ は尤度関数であり, 観測值に正規分布を仮 定すれば,

$$
p(\mathbf{d} \mid \mathbf{m})=\exp [E(\mathbf{m})]
$$

である。従って, 逆解析における misfit から尤度関数の分布を求め れば, データ $\mathbf{d}$ が得られた際のモデル $\mathbf{m}$ の分布ということになる。 MCMC 法では, (4)式によって, 観測值が得られている場合に, モ デルの確率分布を推定し, その分布の平均や標準偏差などの統計量 から逆解析結果を得ることになる 6 。

単純なランダムなサンプリングにより，(4)式の分布を数值的に評 価することもできるが, 多変数の場合には計算量が非常に大きくな り, 現実的ではない。ここでは, Metropolis-Hastings によるアル ゴリズム7)を用いてマルコフ連鎖モンテカルロ（MCMC）法により 式(4)の分布を求めることにする。 MCMC 法は, パラメータのマル コフ連鎖の状態でのサンプリングから，(4)式の確率分布を求める数 值統計的な手法であり, 解析的に目的とする分布の形状が求められ ない場合を対象として開発されたものである。アルゴリズムの詳細 は，山中（2013）6)に示されている。

MCMC 法による逆解析では, 上述のように順計算のみを行うこ とになるので, 微動探查においてよく用いられている遺伝的アルゴ リズムなどのヒューリステック探索法 8) と同様にロバスト性の高い 方法である。これらの特徴に加えて, 推定パラメータの分布がわか るという点もこの方法の有利な点である。最近, MCMC 法は様々 な分野で注目されており 7), 深部地盤を対象とした微動探查による 位相速度の逆解析への適用も検討されている 6 。

\section{3. 逆解析の数值実験}

\section{1 地盤モデルと疑似観測データ}

ここでは, 表層地盤の 3 層モデルを用いて数值実験を行い, レイ リー波の位相速度のばらつきの影響が地盤モデルの推定にどのよう な影響を及ぼすか検討する。用いた S 波速度モデルを Fig.1に示す。 2 つの表層が工学的基盤上に存在するモデルである。 $\mathrm{P}$ 波速度につ いては経験式9ににより $\mathrm{S}$ 波速度から求め, 密度には $1.3,1.5,1.8 \mathrm{~g} / \mathrm{cm}^{3}$ を与えた。このモデルに対寸る基本モードのレイリー波の理論位相 速度を周波数 $2 \sim 30 \mathrm{~Hz}$ の間で計算し, それらに $3 \%$ のランダムノイ ズを与え, 擬似観測位相速度データとした。こうして得られた各周 波数での位相速度の $10 \%$ の值を観測值の標準偏差として与えた。こ
うして得られた擬似観測位相速度が Fig.2 に示されている。

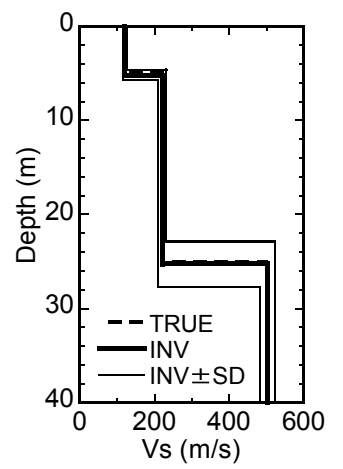

Fig.1 Comparison of inverted Vs model (thick line) with true model (broken line) with standard deviation of inverted model shown by thin lines.

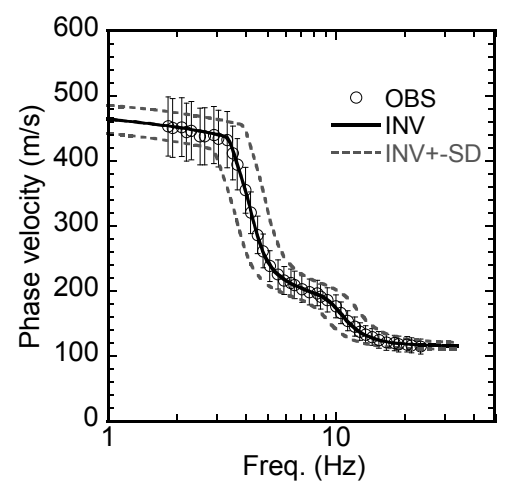

Fig.2 Comparison between synthetic observed phase velocity and theoretical one for inverted model in Fig. 1 shown by circles and a solid line, respectively. The broken lines indicate theoretical phase velocities for the models shown by gray broken lines in Fig. 1 .

\section{2 逆解析結果}

MCMC 法によってサンプリングした地盤モデルのパラメータの 推移の様子が Fig. 3 に示されている。ランダムに発生した初期モデ ルは, 正解值からすれているが, 200 回程度のサンプリングで第 1 層の厚さが大きく変化した後, 正解值の $5 \mathrm{~m}$ 付近でサンプリングが 行われている。また, 約 500 回目では 3 層目と 1 層目の $\mathrm{S}$ 波速度が 正解値に向けて変化し始めている。さらに, 2000 回程度以降には, 2 層目の厚さも大きく変化している。その後, 約 5 千回程度で, す ベてのパラメータが正解值付近でのサンプリング状態に達している。 さらに, 1 万回程度以降では, 正解值周辺で変動しながらサンプリ ングが行われていることがわかる。サンプリングされたモデルに対 する式(1)の誤差の推移を Fig.4 に示す。上述の正解值へのアプロー チと同様に, 200 回程度で誤差が小さくなりはじめ, 1 万回程度で 一定值の周辺を振動している。MCMC 法では, 上記の初期モデル に依存した部分を削除した後の定常的なサンプリング結果がその後 の分析に用いられる。山中 6) と同様に Geweke ${ }^{10)}$ の方法を用いて, この削除する部分を決めた。Fig.3 の場合には, 初めの約 1.4 万個の サンプルを削除し，それ以降を定常的なサンプリングであるとした。

MCMC 法では, 上記のように定常的な状態においてサンプリン グされたモデルを用いて, 各モデルのパラメータの統計量を求める 
ことになる。Fig.5 には, 得られたモデルの S 波速度と厚さの分布 が示されている。各パラメータの分布は, 正解值に近い值を平均と した対称的な分布形であり, その平均值と標準偏差は図中に数值と して示されているとおりである。第 1 層の $\mathrm{S}$ 波速度と厚さについて の標準偏差は小さく, 分解能が非常に高くなっていると考えられる。 また, 2 層目の $\mathrm{S}$ 波速度も分布の幅が比較的狭くなっている。一方, 2 層目の厚さや基盤の $\mathrm{S}$ 波速度の分散はやや大きく, 分解能は相対 的に小さい。これは, 位相速度のデータが $2 \mathrm{~Hz}$ よりも低周波数で得 られていないことの影響であると考えられる。これらの各パラメー 夕の分布の平均值と標準偏差により, 最終的な逆解析モデルとその ばらつきを得ることができる。平均して得られるモデルが正解モデ ルと Fig.1 に比較されている。上述のように, 工学的基盤の深度に やや大きい不確かさはあるが, $\mathrm{S}$ 波速度構造は, 逆解析によってよ く再構成されている。また, Fig. 2 には, 逆解析モデルに対するレ イリー波の理論位相速度が観測值と比較されている。両者はよく一 致しており, 逆解析としても大きな問題はない。さらに, 図には, 平均による逆解析モデルに標準偏差を加減したモデルの理論值も示 されている。これらの 2 つのモデルに対する理論值は, ほぼ観測值 の標準偏差の上限と下限に対応しており, モデルパラメータの不確 かさの分布も適切に評価できていると考えられる。
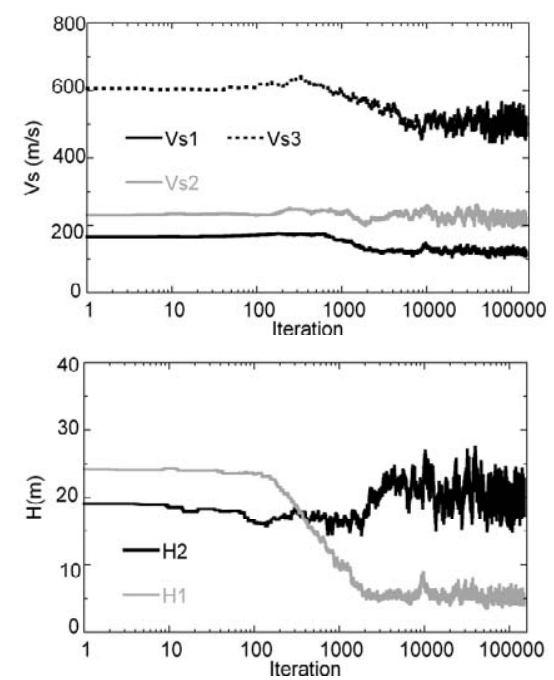

Fig.3 Plots of S-wave velocity (top) and thickness (bottom) against increasing sampling iteration.

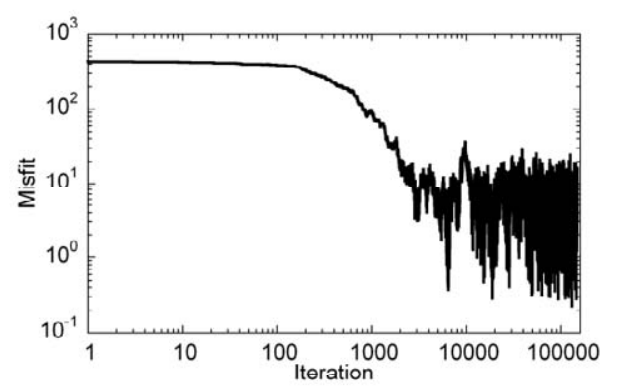

Fig.4 Plot of misfit against increasing sampling iteration.
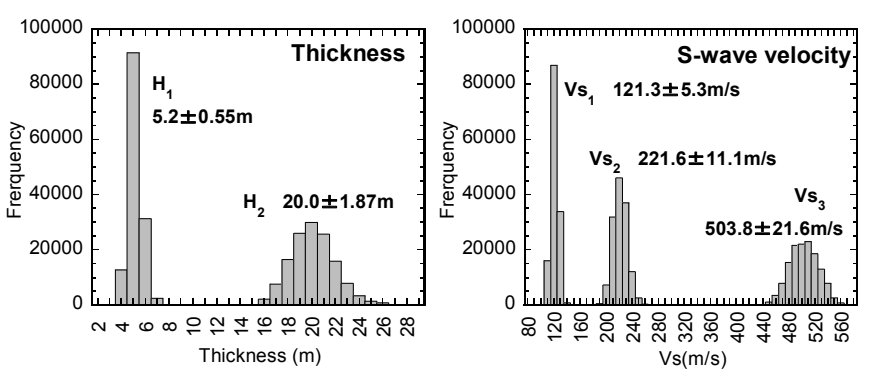

Fig.5 Frequency distributions of S-wave velocity (right) and thickness (left) of sampled models after burn-in period. Numbers attached indicate average and standard deviation for each parameter.

\section{3 トレードオフ関係}

一般的に, レイリ一波の位相速度の逆解析において, $\mathrm{S}$ 波速度と 層厚の間にはトレードオフの関係がある。そこで，上記の数值実験 でサンプリングされた, すべてのモデルを用いて $\mathrm{S}$ 波速度と厚さの 相関関係を調べた。

Fig.6 は, 第 1 層のS 波速度と厚さの関係を示している。両者の 分布には明らかに正の相関，すなわちトレードオフの関係があるこ とがわかる。この分布は, 図の白丸で示した正解モデルの值を中心 に広がっている。Fig.5 の結果も考慮すれば，白丸の周辺で頻度が 高く, 周辺に行くほど低頻度になっていると考えられる。さらに, 1 層目の厚さと 2 層目のS 波速度の関係もFig.6 には示されている。 1 層目の厚さは， 2 層目の S 波速度にも弱い正の相関性があること がわかる。
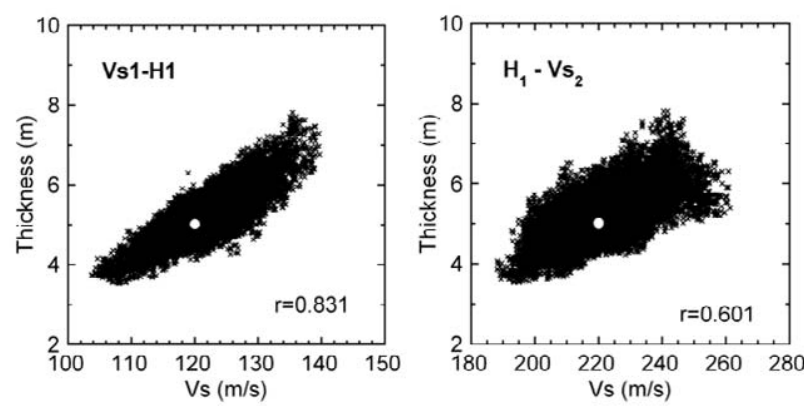

Fig.6 Relationships between S-wave velocity of the first (left) and second (right) layers with thickness of the first layer. A white circle in each panel indicates the parameters for the true model. $r$ in each panel means correlation coefficient.

各パラメータ間の相関関係を理解するために, 相関係数を計算し た。その結果は, Table 1 にまとめられている。表の各要素は, 3 つの $\mathrm{S}$ 波速度 $(\mathrm{Vs})$ と 2 つの層厚 $(\mathrm{H})$ の相関係数を示し, 当然, 対角成分が 1 の対称行列となる。これらは, 最小 2 乗法による逆解 析での分解能行列 11) と同様の意味を持っていると考えられる。すな わち, 他のパラメータとの相関が小さいほど, 各パラメータは独立 に決まり, 分解能が高いことを意味しており, 定量的にパラメータ 
の関係を理解できる。 $\mathrm{S}$ 波速度ざうしの相関係数は小さく, 独立し ていると考えられる。厚さどうしの相関も大きくはない。しかし， Fig.6に示したように, 各層の $\mathrm{S}$ 波速度と層厚には, 相関係数が 0.8 以上と高い相関関係がある。こうしたトレードオフ関係は，位相速 度の逆解析において本質的に避けられないものであり, 事前の情報 を踏まえて, 層厚を与えることや探索範囲を限定寸ることなどより， より高い分解能を得る工夫も必要である。このように, MCMC 法 による逆解析では, 各パラメータの分解能の定量的な評価も容易に できる。このことは, 他のヒューリステック法にはない利点である。

Table 1 Correlation coefficients between parameters.

\begin{tabular}{|c|c|c|c|c|c|}
\hline & Vs1 & Vs2 & Vs3 & H1 & H2 \\
\hline Vs1 & 1.000 & 0.299 & 0.106 & 0.831 & 0.065 \\
\hline Vs2 & & 1.000 & 0.081 & 0.601 & 0.858 \\
\hline Vs3 & & & 1.000 & 0.112 & 0.245 \\
\hline H1 & & & & 1.000 & 0.305 \\
\hline H2 & & & & & 1.000 \\
\hline
\end{tabular}

\section{4. 観測値の誤差の影響}

Fig. 2 に示した疑似観測位相速度の值をそのままにして, 各観測 值の標準偏差のみを 5 から $40 \%$ と変化させて, 同様の逆解析を行っ た。それらの擬似観測データの逆解析による $\mathrm{S}$ 波速度構造モデルは, Fig.7 に示すごとくである。第 1 層の $\mathrm{S}$ 波速度は, どの場合もほぼ 正しく推定されている。これは, 高周波数側の位相速度によって地 盤モデルが強く拘束されることによると考えられる。一方, それ以 外の $\mathrm{S}$ 波速度や厚さについては, 観測データの標準偏差が大きいほ ど, 正解值からずれる傾向がある。とくに, 標準偏差が $30 \%$ 上の 場合には，正解モデルからの乘離が著しい。

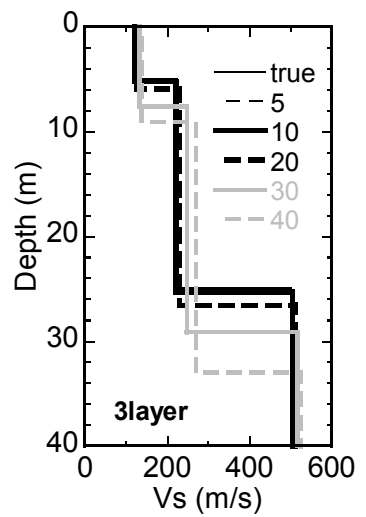

Fig.7 S-wave velocity profiles inverted from synthetic phase velocity with observed standard deviations assumed as 5 to $40 \%$ of the data with true model shown by a thin solid line.

逆解析モデルの各パラメータの標準偏差をその平均值で除した変 動係数と観測位相速度の標準偏差との関係を Fig.8 に示す。観測位 相速度の標準偏差が大きくなると, $\mathrm{S}$ 波速度と層厚のばらつきは大 きくなるが，厚さのほうが観測值のばらつきの影響をより受けやす
くなっている。この結果を大まかにみれば，微動探査での $\mathrm{S}$ 波速度 構造モデルの $\mathrm{S}$ 波速度と厚さの推定精度を共に $10 \%$ 以内にするた めには, す心゙ての周波数での位相速度を約 10\%以内の精度で観測す る必要があることがわかる。
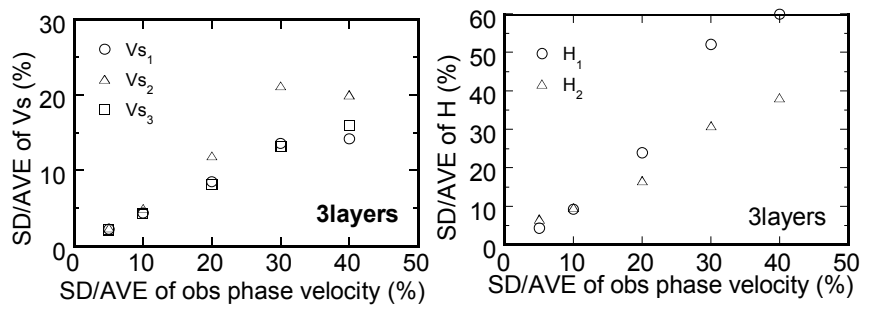

Fig.8 Relationships between variation coefficients of S-wave velocities (left) and thicknesses (right) against standard deviation of synthetic observed data.

\section{5. 地震動評価への影響}

\section{1 増幅特性のばらつき}

上述のようにサンプリングされた結果を用いることによって，微 動探查により得られる位相速度の観測精度から地盤増幅特性のばら つきの評価も可能になる。そのためには，Fig. 1 に示した地盤モデ ルの標準偏差から増幅特性のばらつきを評価する方法とサンプリン グされたす心゙ての地盤モデルから直接増幅特性の頻度分布を求める 方法がある。ここでは，後者を用いることにした。

増幅特性の計算では， 1 次元 $S$ 波入射を仮定し，Q 值は一定值と して,Vs (m/s)の $1 / 5$ を各層に与えた。Fig. 2 に示した擬似観測デー 夕（標準偏差は $10 \%$ ）の MCMC 法による逆解析でサンプリングされた 各地盤モデルの増幅特性を計算し，それらを用いて統計量を得た。 Fig. 9 には, サンプリングされたす心゙てのモデルの増幅特性の平均 值とその標準偏差が示されている。図には，ハイブリッドヒューリ スティック法 ${ }^{8)}$ による逆解析から得られた 1 つの最適な逆解析モデ ル（以下，ハイブリッド法によるモデル）に対する増幅特性も比較 されている。周期 0.5 秒の基本モード付近の増幅特性には，位相速 度の観測值のばらつきの影響はほとんど認められず，ハイブリッド 法によるモデルの増幅特性とも一致している。周期 0.2 秒の最大值 となるピークでは, 平均した増幅特性のほうがやや小さい。さらに， より短周期帯域では，ハイブリッド法によるモデルの増幅特性にみ られる山谷の差が MCMC 法による平均増幅特性では小さくなり, 平均 増幅特性はスムーズになっていることがわかる。これは, サンプリ ングされた個々のモデルの増幅特性における高次モードのピークと 谷の周期が短周期帯域ではそれぞれ異なるために，平均することに よって打ち消されていることが原因である。位相速度の観測值の誤 差を考えると，短周期のピークや谷の信頼性が低く，平均的なレベ ルのみが信頼できる評価量と解釈す心゙きであると考えられる。また， このハイブリッド法による地盤増幅特性は，す心゙ての周期帯域でサ ンプリングされたモデルの増幅特性の標準偏差の範囲に収まってお り，平均増幅特性との差は，ばらつきの範囲内である。すなわち， ハイブリッド法による地盤モデルも位相速度を満足する多くのモデ ルのひとつのサンプルであることを意味している。 


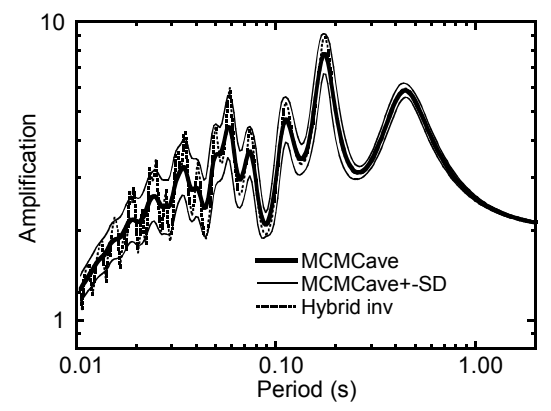

Fig.9 Comparison of amplification factors of 1D S-wave in models sampled with MCMC inversion with that from conventional inversion shown by thick and broken lines, respectively. Thin broken lines indicate standard deviations of amplification of sampled models.

\section{2 観測誤差の影響}

上記と同様にして, 観測位相速度の標準偏差が地盤増幅特性に及 ぼす影響を調べる。上述の数值実験において実施した異なる標準偏 差を仮定した位相速度の逆解析時にサンプリングされた結果を用い て，増幅特性を計算した。Fig.10には，それぞれの場合の増幅特性 の平均值が比較されている。基本モードの卓越周期付近では, どの 場合にも増幅特性は類似している。上述のように, 基本モードの増 幅率に対しては，観測值のばらつきの影響は小さいことがわかる。 一方, 周期 0.2 秒よりも短周期では, 観測值のばらつきが大きいほ ど, 高次モードのピークが小さくなり, 増幅特性は滑らかな形状に なっている。とくに, 標準偏差が $30 \%$ 上小場合には, 基本モード 以外のピークが認められない。Fig.10には, 増幅特性の標準偏差も 比較されている。周期 0.2 秒付近の増幅特性に観測值のばらつきが 最も強く影響し, 基本モードのピーク周期付近では, その影響が小 さくなることがわかる。さらに，0.1秒以下の短周期でも観測值の ばらつきの影響は小さくなる。上述のように，これも短周期でのピ 一クと谷が各モデルで少しずつ異なっているために打ち消された結 果であると考えられる。この平滑化の効果は, 観測值のばらつきが 大きいほど，より長い周期まで影響していると考えられる。観測値 のばらつきの影響を考慮せずに, 通常の逆解析のように, ひとつの 地盤モデルに基づいて増幅特性を評価すると, 高次モードのピーク 周期では大き目になり, 谷の部分では過小評価している可能性が高 い。地盤増幅特性の評価を目的とした微動探査では, 位相速度の逆 解析に観測值のばらつきの影響を考慮し, 議論できる増幅特性の周 期範囲と精度を理解しておくことが重要であると考えられる。

Fig.11には, 基本モードのピークと最大増幅率を示すピークの周 期とその振幅の変化（変動係数）が観測位相速度の標準偏差に対し てプロットされている。基本モードでは, ピーク周期とその振幅は, 観測のばらつきに対してほぼ線形な関係を示している。この図から, 10\%精度で基本モードのピーク周期やその増幅倍率を評価するには, $20 \%$ 程度で精度での位相速度の観測が必要となることがわかる。一 方, 最大増幅率を示すピーク周期については, 観測値のばらつきが 大きいほど, その変動が大きくなっている。とくに, 観測值の標準 偏差が $20 \%$ 以上で, ピーク周期の変動係数が急に大きくなっている。
観測値のばらつきが小さい場合には，す心゙てのサンプリングされた モデルで最大増幅率は, 周期 0.2 秒付近の高次モードのピークによ ると考えられる。一方, 観測值のばらつきが大きいと, モデルによ って最大増幅率を示すモードが異なってくるために，ピーク周期の 変動はより大きくなっていると考えられる。
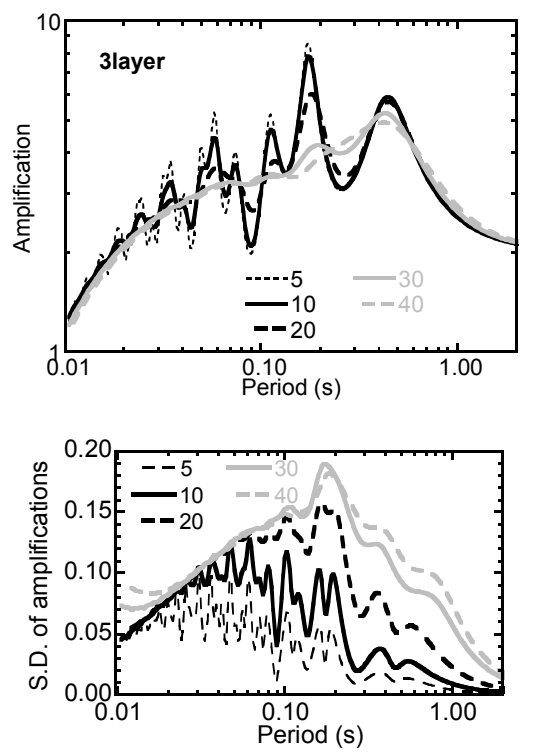

Fig.10 Averaged spectra (top) and standard deviations (bottom) of amplification factors of 1D S-wave in models sampled with MCMC inversion of synthetic data with standard deviations of 5 to $40 \%$.

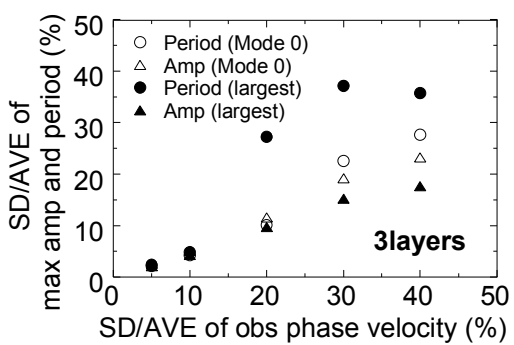

Fig.11 Relationship between variation coefficients of the maximum values and predominant periods of amplification factors against standard deviation of synthetic observed data.

\section{3 平均 $\mathrm{S}$ 波速度への影響}

地盤増幅を簡易に評価するために, 深度 $30 \mathrm{~m}$ までの平均 $\mathrm{S}$ 波速度 (以下，AVS30）が使われている。そこで，上記のサンプリング結 果を用いて，位相速度のばらつきが及ぼす AVS30 一の影響も検討 した。Fig.12には, 観測值の標準偏差が 10\%の場合にサンプリング された地盤モデルの AVS30 の頻度分布が示されている。正解モデ ルの $210 \mathrm{~m} / \mathrm{s}$ と中心にして非常に狭い分布形であり, AVS30に対す る位相速度の観測值のばらつきの影響が非常に小さいことがわかる。 AVS30 は, 波長 $40 \mathrm{~m}$ のレイリー波の位相速度と関係が深いことが 知られている ${ }^{12)}$ 。サンプリングされた地盤モデルは, 周波数 $2-30 \mathrm{~Hz}$ のレイリー波の位相速度によって担保されているので, どのモデル も類似したAVS30 を持っていると考えられる。これは，ほかの地 
盤調查法にはない微動探查に基づく方法の特徵であると考えられる。 観測値の標準偏差を変えた場合についても AVS30 の分布を調心 た結果も Fig.12 には示されている。どの場合も AVS30 への影響は 小さく, 観測值の標準偏差が 40\%もあった場合でも, AVS30 の精 度は $10 \%$ 以下になっており, AVS30 の評価に微動探查法が有効で あることを示唆している。
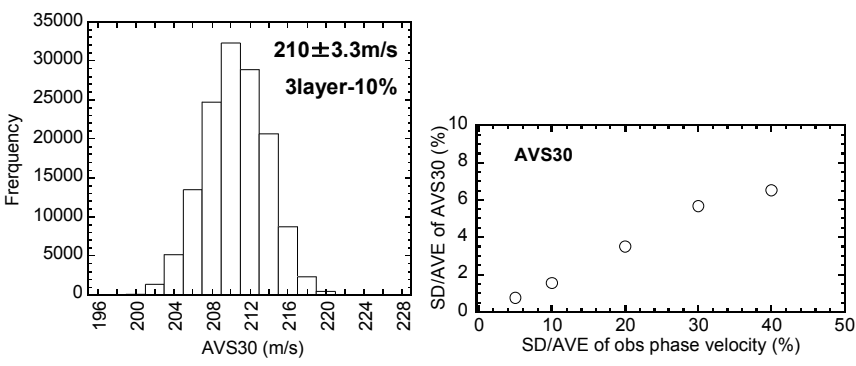

Fig.12 Distribution of AVS30s (left) for models sampled in inversion of phase velocity with standard deviation of $10 \%$, and relationship (right) between variation coefficients of the AVS30s against standard deviation of synthetic observed data.

\section{4 最大加速度 · 速度への影響}

位相速度のばらつきの影響として, 最大加速度 (PGA) や最大速 度 (PGV) についても検討した。ここでは, まず, 告示 (平成 12 年建設省告示第 1461 号) に示されている応答スペクトルと適合寸 る模擬地震波（いわゆる告示波）を作成し, それを工学的基盤での 入力波として, サンプリングされたすべての地盤モデルでの 1 次元 $\mathrm{S}$ 波増幅特性（線形）を考慮して地表面の地震動を計算した。その 結果から各モデルでの地表面での PGA や PGV の分布を求めた。こ こでは, 比較のために, すべてのモデルの工学的基盤の $\mathrm{S}$ 波速度を $500 \mathrm{~m} / \mathrm{s}$ として計算を行った。
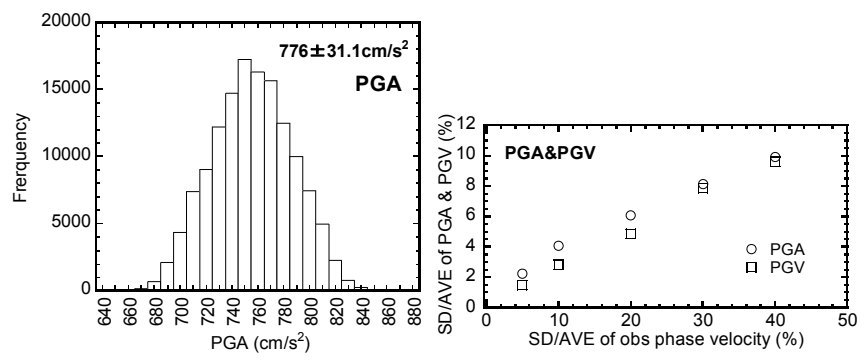

Fig.13 Frequency distribution (left) of PGA on the surface considering amplifications of sampled models. Right panel shows relationships between variation coefficients of PGA and PGV against standard deviation of synthetic observed data.

Fig.13 には, 観測值の標準偏差が 10\%の場合の PGA の分布が示 されている。PGAへの影響は小さく, 数\%程度の標準偏差になって いる。PGVについては示していないが, 同様の傾向である。さらに, 図には, 観測值の標準偏差を変えた場合の PGA と PGV の変動係数
が示されている。上述の AVS30 の場合と同様に，位相速度が $40 \%$ の標準偏差を持つ場合でも, PGA や PGV は 10\%の精度以内になっ ており，位相速度によって担保された地盤モデルが地震動評価には 有効となることを示している。なお，この検討結果は，線形地盤増 幅を仮定した場合の結果であり，地盤の非線形応答を考慮した場合 には，当然のことながら異なると考えられる。

\section{6. 実データへの適用}

MCMC 法による逆解析を 2007 年能登半島沖地震の被災地域で の微動探查 13 によよって得られたレイリー波の位相速度に適用する ことを試みた。対称地域は, 石川県輪島市門前町道下地域であり, 能登半島沖地震の震源域に近く, 同地震による木造家屋などの被害 が多い地域に対応している。山中ほか ${ }^{13)}$ は, Fig.14 に示すように, この地域の数地点で微動探查を実施し, 表層地盤の $\mathrm{S}$ 波速度構造を 推定している。さらに, 能登半島沖地震の余震による地震観測から $\mathrm{S}$ 波部分の増幅特性を求め, 表層地盤モデルから期待される理論増 幅特性との比較も行っている。ここでは，山中ほか 13)による微動探 查地点の L5 で得られた位相速度に対して MCMC 法を用いた再検 討を行う。

Fig.14には, 得られたレイリー波の位相速度が示されている。位 相速度は, $4 \mathrm{~Hz}$ 以上で標準偏差も小さく精度は高いが，それ以下の 周波数では, 観測值の精度が低くなっている。山中ほか 13)を参考に して，4層モデルを仮定して，MCMC 法による逆解析結果を行っ た。推定された S 波速度構造は, Fig.15に示されている。図には, 比較のためにハイブリッド法による逆解析結果 13)も示されている。 深さ $30 \mathrm{~m}$ 程度の第 3 層上面までは, 2 つの逆解析結果は一致し, MCMCM法による推定誤差も小さく, 観測位相速度によって十分に 拘束されていると考えられる。しかし，工学的基盤の深度について は，両者で大きな差異が認められる。しかも，MCMC 法よるモデ ルでは, 工学的基盤の深度の不確かさも大きくなっている。これは, $4 \mathrm{~Hz}$ 以下の周波数帯域での観測位相速度の標準偏差が大きくなって いることが原因である。また，後述するように，3層目の厚さと 3 ， 4 層目のS 波速度のトレードオフの関係も工学的基盤の深度の不確 かさに影響していると考えられる。工学的基盤の $\mathrm{S}$ 波速度のばらつ きもその他の層の $\mathrm{S}$ 波速度に比べて大きくなっている。これは, $3 \mathrm{~Hz}$ 以下で観測位相速度が得られていないことが原因である。2つの逆 解析モデルに対寸る基本モードのレイリー波位相速度も Fig.14 で 観測值と比較されている。周波数 $3 \mathrm{~Hz}$ 以上では両モデルで大差なく, よく観測值を説明している。一方，それ以下の周波数では，2つの モデルが異なる理論値を示している。しかし，観測值の誤差を考慮 寸れば，その範囲では両モデルとも観測值を説明していると考えら れる。

各パラメータ間の相関倸数は, Fig.16 に示されている。左図は, 各パラメータのS 波速度に, 右図は層厚に対する相関係数を示して いる。各層のS 波速度は，他の層のS 波速度とは，相関性は低い。 上述の数值計算の場合と異なり, 同じ層の $\mathrm{S}$ 波速度と厚さとの相関 は，0.5 程度とやや低い。一方，第 $1 ， 2$ 層の層厚の間には，弱い 逆相関関係がある。

得られた地盤モデルを用いて，増幅特性の評価を行った。Fig.17 には, サンプリングされたモデルの増幅特性の平均值と土標準偏差 
が示されている。さらに, この図には, ハイブリッド法によるモデ ルの理論増幅特性と増幅特性の観測值 13)も示されている。MCMC 法による増幅特性は, 一部の周期でハイブリッド法の増幅特性と異 なる。さらに, MCMC 法の増幅特性の山谷は, 多少平滑化されて いるが，増幅特性の標準偏差を考慮すれば，全体的には両者は類似 した結果であると考えられる。また, 今回評価した理論増幅率でも, 余震による地震記録のスペクトル比とは卓越周期付近で大きく異な り, 増幅特性のばらつきを考慮しても, 説明することができなかっ た。工学的基盤の $\mathrm{S}$ 波速度のばらつきがやや大きいことも両者の差 の一因と考えられるが, 山中ほか 13)の指摘のとおり, 1 次元モデル では説明できない可能も否定できない。

サンプリングされた地盤モデルに対する AVS30 についても評価 した。MCMC 法による逆解析の結果では, AVS30 が $205 \pm 4.9 \mathrm{~m} / \mathrm{s}$ となった。山中ほか 13)によるモデルでは, AVS30 は $201 \mathrm{~m} / \mathrm{s}$ であり, 両者に大きな差異はない。これは, 高周波数の位相速度の観測値の 精度が高いために, 深度 $30 \mathrm{~m}$ 程度までの地盤モデルに強い拘束が効 いており，モデルに大きな差異が生じなかったことによるものであ る。

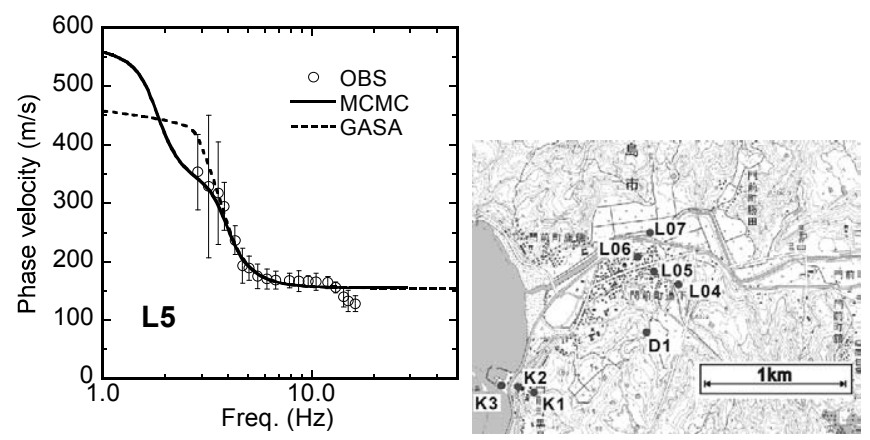

Fig.14 Comparison of observed phase velocity from microtremor exploration by Yamanaka et al. ${ }^{13)}$ by circles with theoretical ones from inversions with MCMC method and conventional method shown by solid and broken lines.

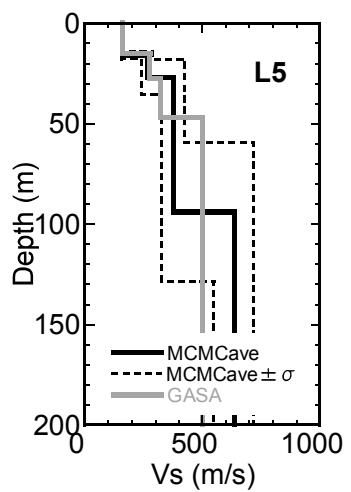

Fig.15 S-wave velocity profiles from MCMC and conventional inversions of phase velocity in Fig.14 shown by black and gray lines, respectively. Broken lines show models from average with plus or minus a standard deviation from MCMC inversion.

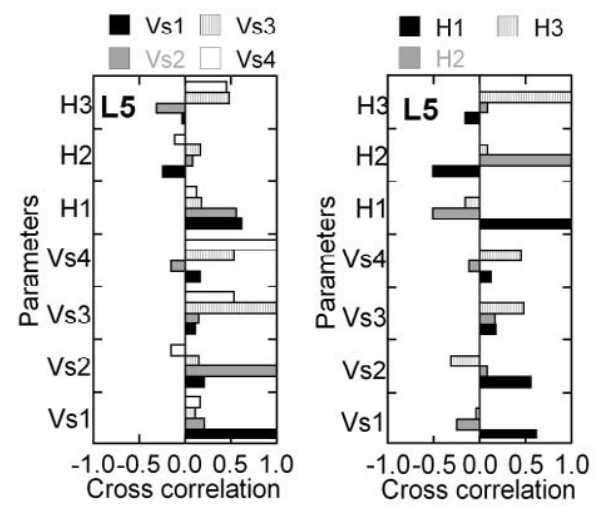

Fig.16 Correlation coefficients of parameters with S-wave velocity (left) and thickness (right) of sampled models in MCMC inversion of phase velocity in Fig. 14.

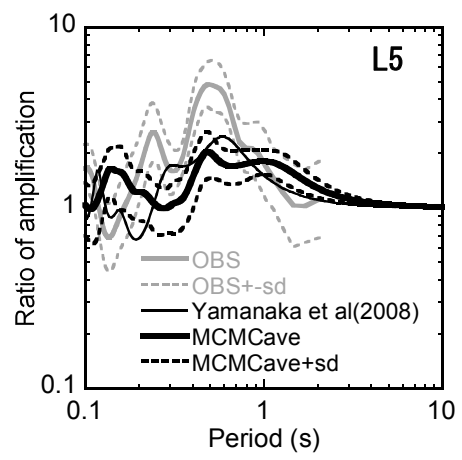

Fig.17 Comparison of 1D amplifications for S-wave velocity profiles from MCMC and conventional inversions in Fig.14 shown by black and thin lines, respectively, with observed one (gray line) by Yamanaka et al. ${ }^{13)}$. Solid broken lines show standard deviation of amplification factors for sampled models in MCMC inversion, while gray broken lines indicate that of the observed one.

\section{7. まとめ}

微動探査で得られる表面波の位相速度の逆解析に MCMC 法を適 用することを試み，レイリー波の位相速度の観測誤差から表層地盤 のS 波速度構造のばらつきの評価の可能性を検討した。表層地盤の レイリー波の位相速度の計算值から擬似観測データを作成し, $\mathrm{MCMC}$ 法の逆解析の数值実験を行った。サンプリングされたモデ ル群を用いて評価したパラメータの頻度分布から逆解析結果を得る ことができた。すなわち，それらの分布の平均值と標準偏差によっ て, 逆解析モデルとその精度を推定した。この逆解析では, 順計算 を行い，モデルをサンプリングするだけであり，従来のヒューリス テック法と同様に高いロバスト性がある。しかも, 推定モデルパラ メータの精度や分解能も簡単に評価できることは有利な点である。 さらに，モデルパラメータの精度だけでなく，それを用いた様々な 地盤増幅特性のばらつきの評価することが可能となった。これは, 地盤調査の結果の精度と地震動評価のばらつきを直接結びつけるも のであり，地盤モデルのユーザーから地盤調査において目標となる 観測精度の要求も行うことができると考えられる。 
本研究では, 限られた地盤モデルでの線形地盤応答のみについて 検討を行ったが, 今後は, 位相速度の観測值のばらつきが多様な地 盤条件での非線形地盤応答へ及ぼす影響も検討することを考えてい る。さらに, MCMC 法は他の物理量の逆解析への適用可能性が高 く，地震記録の分析への適用も検討寸る予定である。

\section{謝辞}

2 名の查読者からは，貴重なご意見を頂きました。本研究での地 盤応答解析での入力波の作成では, 鉄道総合技術研究所の津野靖士 博士のご協力を頂きました。本研究の一部は, 文部科学省科学研究 費補助金基盤研究 (B)（22310108）の支援を受けて行われました。記

して感謝いたします。

\section{参考文献}

1) 岡田 廣, 松島 健, 森谷武男, 笹谷 努: 広域·深層地盤調査のための長周 期微動探查法，物理探査，第 43 巻，pp. 402-417，1990. 12 .

2) 時松孝次, 新井 洋, 酒井潤也 : 短周期微動に含まれる表面波の性質と地盤 構造の関係, 日本建築学会構造系論文集, No. 472, pp. 47-55, 1995.6.

3) 山中浩明, 山田伸之: 強震動評価のための関東平野の 3 次元 S 波速度構造 モデルの構築, 物理探査, 第 59 巻, pp. 549-560, 2006.12 .
4) 山中浩明, 石田 寞：遺伝的アルゴリズムによる位相速度の逆解析, 日本 建築学会構造系論文集, No. 468, pp. 9-17, 1995.2.

5)物理探査学会 : 新版物理探査適用の手引き, pp. 123-124, 2008. 10.

6) 山中浩明 : マルコフ連鎖モンテカルロ法による表面波の位相速度の逆解析, 物理探查, 第 66 巻, pp. 97-110, 2013.7.

7）伊庭幸人：マルコフ連鎖モンテカルロ法の基礎，計算統計 II マルコフ連鎖 モンテカルロ法とその周辺，岩波書店，pp.1-106，2005. 10.

8) 山中浩明: ハイブリッドヒューリスティック探索による位相速度の逆解析, 物理探査, 第 60 巻, pp. $265-275,2007.6$.

9) 狐崎長琅, 後藤典俊, 小林芳正, 井川 猛, 堀家正則, 斎藤徳美, 黒田 徹, 山根一修, 奥住宏一：地震動予測のための深層地盤 $\mathrm{P} ・ \mathrm{~S}$ 波速度の推定, 自然災害科学，第 9 巻， 3 号，pp. 1-17，1990.11

10) Geweke, J. : Evaluating the accuracy of sampling-based approaches to the calculation of posterior moments, Bayesian statistics 4, Oxford Univ. Press, pp.169-193, 1992

11) Menke, W.: Geophysical data analysis: Discrete inverse theory, Academic Press Inc., 1989.

12) 紺野克昭, 片岡俊一: レイリー波の位相速度から地盤の平均 S 波速度を直 接推定寸る方法の提案, 土木学会論文集, 第 647 号, / I - 51，pp. 415-423, 2000. 4 .

13) 山中浩明, 元木健太郎, 山田伸之, 福元俊一, 山田悦子, 瀬尾和大 : 2007 年能登半島地震の余震観測と微動探查による輪島市門前町の地盤震動特性 の評価，物理探查，第 61 巻，pp. 385-396, 2008. 10. 


\title{
ESTIMATION OF MODEL UNCERTAINTY OF S-WAVE VELOCITY PROFILE FROM INVERSION OF SURFACE-WAVE PHASE VELOCITY USING MCMC METHOD
}

\author{
Hiroaki YAMANAKA* \\ * Prof., Interdisciplinary Graduate School of Science and Engineering, Tokyo Institute of Technology, Dr. Eng.
}

In this study, an applicability of Markov Chain Monte Carlo (MCMC in the following) method is examined in surface-wave phase velocity inversion for an estimation of shallow S-wave profiling with uncertainty of model parameters. The MCMC inversion samples models based on misfit values with the Metropolis-Hasting procedure. Therefore this method requires only calculation of forward modeling for the estimation of the misfit as similar to the other heuristic methods. The MCMC inversion finds an optimal model from averaging S-wave velocity and thickness for the sampled models. We can also estimate resolutions for the model parameters using their standard deviations for the distribution of the sampled models. Numerical examinations of the method were conducted using synthetic fundamental Rayleigh wave phase velocity at frequencies from 2 to $20 \mathrm{~Hz}$ in a layered model of a shallow soil over the engineering bedrock. The inverted model in the numerical experiments was similar to the true model with small standard deviations of the parameters. We furthermore conducted numerical experiments using the synthetic phase velocities having different observational standard deviations. The accuracy of the model parameters are closely related with the observational standard deviations. The sampled models were also used to evaluate variations of one-dimensional amplification factors for S-waves. The variation coefficients of dominant periods and their amplitudes depend on the observed errors of the phase velocity, while amplification factors at high frequency are smoothed showing the large uncertainty of high-frequency peaks.

We furthermore applied the method to actual phase velocity data obtained in microtremor explorations in a damaged area during the 2007 Noto-Hanto earthquake, Japan, by Yamanaka et al. (2007). The inverted S-wave velocity profile is almost the same as that from previous inversions. We found the large uncertainty for the depth to the engineering bedrock, because of large observational errors of the phase velocities at long-period. However it is indicated that the amplification at high frequency is not accurately estimated from the explorations considering the uncertainty of the model as similar to the results in the numerical tests. The numerical experiments and the actual application clearly demonstrate a high applicability in the phase velocity inversion with additional advantage for estimation of accuracy of model parameters in shallow S-wave velocity profiling for estimation of amplification of $\mathrm{S}$-waves together with their uncertainty. 